\title{
Amniyat dar eġmā, negāhī be jelve-hā-ye sūrre'ālīsm-e sīyāsī dar İrān. Tehrān, Naqš va negār, 1379/2000, 240 p.
}

\section{Eric Butel}

\section{(2) OpenEdition}

Journals

Édition électronique

URL : http://journals.openedition.org/abstractairanica/35665

DOI : $10.4000 /$ abstractairanica.35665

ISSN : 1961-960X

Éditeur :

CNRS (UMR 7528 Mondes iraniens et indiens), Éditions de l'IFRI

\section{Édition imprimée}

Date de publication : 15 mai 2002

ISSN : 0240-8910

Référence électronique

Eric Butel, « Amniyat dar eg̉mā, negāhī be jelve-hā-ye sūrre'âlīsm-e sīyāsī dar İrān. Tehrān, Naqš va negār, 1379/2000, 240 p. », Abstracta Iranica [En ligne], Volume 23 | 2002, document 352, mis en ligne le 08 février 2010, consulté le 25 septembre 2020. URL : http://journals.openedition.org/ abstractairanica/35665; DOI : https://doi.org/10.4000/abstractairanica.35665

Ce document a été généré automatiquement le 25 septembre 2020

Tous droits réservés 


\section{Amniyat dar ègmā, negāhī be jelve- hā-ye sūrre'ālīsm-e sīyāsī dar Īrān. Tehrān, Naqš va negār, 1379/2000, $240 \mathrm{p}$.}

\section{Eric Butel}

1 Cet ouvrage rassemble les éditoriaux de politique intérieure publiés par Seyyed Morteḍā Mardīhā dans le journal rénovateur iranien 'Așr-e āzādegān, ainsi que certains autres qui n'ayant pu être publiés en Iran après la fermeture du journal, l'ont été parfois à l'étranger. Investie d'une responsabilité politique exceptionnelle en l'absence de véritables partis politiques, la nouvelle presse iranienne d'opposition a publié entre 1997 et 2000 des analyses dont la portée a dépassé de très loin celle des articles de presse ordinaires. Pour Mardīhā, la publication de cette compilation est une invitation à continuer la lutte pour la liberté d'expression en Iran par d'autres moyens, en redonnant au public un accès à des textes donnés à voir dès lors non plus comme des commentaires contingents mais des textes fondateurs de l'idéologie réformatrice.

\section{INDEX}

Thèmes : 13.1. Iran 
AUTEURS

ERIC BUTEL

Paris 